\title{
HUMAN RIGHT DIMENSION IN HEALTH SERVICE (Functional Relation among Doctor, Patient, and Hospital) $^{\Omega}$
}

\author{
Bekti Suharto \\ Doctoral Program Postgraduate School, Universitas Muhammadiyah Surakarta - Indonesia \\ E-mail: bektisuharto@gmail.com
}

\begin{abstract}
This research aimed at analyzing exposure of global capitalism which undermines sense humanity in health services in Indonesia, explaining health care policy, and designing model of functional relationship among doctors, patients, and hospitals, based on human rights. This qualitative research used socio-legal approach. Primary and secondary data were collected by using observation, interviews, and documentation study. Data were analyzed through interactive data analysis process. It found sense of humanity in health services was undermined due to health market laws. Health care policy was a form of health development plan based on law principles which fulfill human rights of health, in terms of its functional relationship among doctors, patients, and hospitals, carried out by implementation of Pancasila, Leadership Trilogy of Ki Hajar Dewantara, Tri Dharma teachings of Mangkunegara I, KH. Ahmad Dahlan teachings, and teachings of Shiddiq, amanah, tabligh, fathonah, either by hospitals, doctors, and patients, on administrative, medical, or social services.
\end{abstract}

Keywords: capitalism, health legal policy, human rights dimension, health service.

\begin{abstract}
Abstrak
Penelitian ini bertujuan untuk menganalisis tentang terjadinya terpaan kapitalisme global yang mengikis rasa kemanusiaan dalam jasa pelayanan kesehatan di Indonesia, menjabarkan tentang kebijakan pelayanan kesehatan, dan mencari model hubungan fungsional antara dokter, pasien, dan rumah sakit ke depan menurut HAM. Penelitian kualitatif ini menggunakan pendekatan socio-legal. Data primer dan data sekunder, yang dikumpulkan menggunakan observasi, wawancara, dan studi dokumentasi, dianalisis melalui proses analisis data secara interaktif. Dalam penelitian ditemukan pengikisan rasa kemanusiaan dalam jasa pelayanan kesehatan oleh hukum pasar kesehatan. Kebijakan pelayanan kesehatan merupakan wujud rencana pembangunan kesehatan yang dilandasi asas-asas hukum, yang memenuhi HAM atas kesehatan, dalam hubungan fungsional antara dokter, pasien, dan rumah sakit, yang dilaksanakan dengan pengamalan Pancasila, Trilogi Kepemimpinan dari Ki Hajar Dewantara, ajaran Tri Dharma dari Mangkunegara I, ajaran KH. Ahmad Dahlan, dan ajaran sifat shiddiq, amanah, tabligh, dan fathonah, baik oleh rumah sakit, dokter, maupun pasien, dalam pelayanan administratif, pelayanan medis, ataupun pelayanan sosial.
\end{abstract}

Kata kunci: kapitalisme, politik hukum kesehatan, dimensi HAM, layanan kesehatan

\section{Introduction}

The rights to health care in relation to health and medical law is patient's rights. ${ }^{1} \mathrm{~Pa}$ tient rights on health care coming from human relationship between doctor and patient has become global concerns for years. That opens up

$\Omega \quad$ This Paper is part of the author's dissertation at Doctoral Program Postgraduate School Universitas Muhammadiyah Surakarta

1 Scott L Greer, Et.Al. "Health Law and Policy in the European Union", The Lancet, Vol. 381 No. 9872, March 2013, p. $1135-1144$ a new dimension to develop and improve new branch of law science namely medical law and health law. ${ }^{2}$ Health care is every human's right. The Government is aware that healthy people is an asset and goal in achieving a fair and prosperous society. Hospital is often seen as a unilateral or one-sided relationship which puts patients is in a helpless position, even for those

Endang Kusuma Astuti, 2003, Hubungan Hukum antara Dokter dengan Pasien dalam Upaya Pelayanan Medis di Rumah Sakit, Semarang: Law Doctoral Program Universitas Diponegoro, p. 61-62. 
who are first admitted to hospital. Usually the patient comes to a doctor or hospital in severe condition expecting for better treatment by doctor or hospital who take care of them fully. They do not care anymore what the doctor will do for their illness. ${ }^{3}$ This condition actually describes the culture position that patients seem actively undercut their position toward human rights. Human rights culture is still weak in society related to their health.

Based on data obtained in previous studies, several problems arise from poor relationship between doctors, patients, and the hospital that must be solved to obtain a harmonious condition in the patient's service by doctors and hospitals, both for health services as well as for administrative services. ${ }^{4}$ Communication among doctors, patients, and the hospital is also needed so there would be no dissatisfaction and conflict among them. ${ }^{5}$ The fear of the community of the hospital's role is no longer based on mutual help and more worried about economic factors rather than humanities. It also raises many problems regarding the function of hospitals as a means of service, recognized health which can provide medical services properly and restore public confidence. ${ }^{6}$ Although several policies have been set up on the relationship bet-

3 Kevin T Kavanagh, Daniel M Saman, Et.Al. "Estimating Hospital-Related Deaths Due to Medical Error: a Perspective from Patient Advocates", Journal of Patient Safety, Vol. 13 No. 1, March 2011, p. 1; James, John T. "A New, Evidence-based Estimate of Patient Harms Associated with Hospital Care". Journal of Patient Safety, Vol. 9 No. 3, September 2013, p. 122.

4 Based on structured interview with some interviewees and observation conducted on April-November 2015, in Dr. Moewardi Regional Public Hospital and PKU Muhammadiyah Hospital Surakarta.

5 Gaurav Banka, Sarah Edgington, Namgyal Kyulo, Et.Al., "Improving Patient Satisfaction Through Physician Education, Feedback, and Incentives", Journal of Hospital Medicine, Vol. 10 No. 8, May 2015. p. 497; Amitav Banerjee and Debmitra Sanyal, "Dynamics of Doctor-Patient Relationship: a Cross-sectional Study on Concordance, Trust, and Patient Enablement", Journal of Family and Community Medicine, Vol. 19 No. 1, JanuaryApril 2012, p. 12.

6 Sarah L. Clever, Et.Al., "Does Doctor-Patient Communication Affect Patient Satisfaction with Hospital Care? Results of an Analysis with a Novel Instrument Variable", Health Services Research Journal. Vol. 43 No. 5, October 2008, p. 1506. It also revealed in Van Mo Dang, Patrice Francois, Et.Al. "Medical Record-Keeping Patient Perception of Hospital Care Quality", International Journal of Health Care Quality Assurance, Vol. 27 No. 6, 2014, p. 531. ween patients and hospitals, there are still many flaws in the implementation. One of them is human rights issues in health services which should be improved including violation of informed consent, neglect patients, ${ }^{7}$ malpractice, ${ }^{8}$ drugs abuse, ${ }^{9}$ capitalism in the field of health services, and discriminatory services. Hospital is also often seen as a unilateral or one-sided relationship, and the patient is in a helpless position, and other violence. Thus, the Government as the political laws maker in the field overcome it as well as hospital as a means of health care services.

The law issues examined in this article are: first, how health care policy is related to the functional relationship among doctors, patients, and hospital?; second, how is the model of functional relationship among physicians, patients, and hospital to the next according to human rights related to health care policy in Indonesia?

\section{Research Method}

This qualitative research applies socio-legal approach comprehensively. The research is conducted in Dr. Moewardi Regional Public Hospital and Pusat Kesehatan Umum/Public Health Center (PKU) Muhammadiyah Hospital Surakarta, in April until November 2015. The primary and secondary data were collected by using documentation study, direct observation, indepth interview with some interviewees including key informant, Hospital Director, main informants involving doctors, patients, medical committee, also deputy director and the hospital staff

7 This cases also happened, see Sara Rosenbaum, Et.Al., “Case Studies at Denver Health: 'Patient Dumping' in the Emergency Department Despite EMTALA, the Law that Banned it", Health Affairs, Vol. 31 No. 8, August 2012, p. 1749.

8 Landrigan, CP., Et.Al., "Temporal Trends in Rates of Patient Harm Resulting from Medical Care”. New England Journal of Medicine, Vol. 363 No. 22, November 2010, p. 2124; SJ. Weiner, A. Schwartz, Et.Al., "Contextual Errors and Failures in Individualizing Patient Care: A Multicenter Study", Annals of Internal Medicine, Vol. 153 No. 2, July 2010, p. 69.

9 Takashi Watanabe, Et.Al., “Assessment of Japanese Stimulant Control Law Offenders Using the Addiction Severity Index-Japanese Version: Comparison with $\mathrm{Pa}$ tients in Treatment Settings", International Journal of Enviromental Research and Public Health, Vol. 6 No. 12, December 2009, p. 3056. 
selected based on their knowledge of research topic who engaged directly in the field and understand about the problems especially in how functional relationship among physicians, patients, and hospital. Then the data is analyzed using interactive data analysis process.

\section{Discussion \\ Health Care Policy Related to the Functional Relationship among Doctors, Patients, and Hospital}

From the aspect of national development strategies, good quality of health care is organization form of basic needs. In health care, humanistic dimension over human values always be a basis of the Providence Health. ${ }^{10}$ However, the development of capitalism that emphasizes the power of free trade making the health care commercialization cannot be eliminated.

Capitalism in health services, mainly hospitals, is defined as granting permits and encouraging the private or overseas to participate and earn profit. ${ }^{11}$ However, since major society has low economic condition, private hospital will not be interested to reach lower class. From economic aspect, the investors are not interested because it is surely less favorable. However, it should be reconsidered so that the Government can compel or induce the private sector to serve the poor area. Besides health services by the private sector, there is also a social institution (foundation) which serves as a social institution (non-profit) or company profit pursuers. Health industry market pluralism (mainly hospitals) with the presence of this foundation is a safety against the occurrence of cartels and

10 Ali Mohammad Mosadeghrad, "Healthcare Service Quality: Towards a Broad Definition", International Journal of Health Care Quality Assurance, Vol. 26 No. 3, November 2013, p. 203; Anita C. Keller, MM. Bergman, Et.Al., “The Relationship between Hospital Patients' Ratings of Quality of Care and Communication", International Journal for Quality in Health Care, Vol. 26 No. 1, February 2014, p. 26.

11 Howard Brody and Donald W Light, "The Inverse Benefit Law: How Drug Marketing Undermines Patient Safety and Public Health", American Journal of Public Health, Vol. 101 No. 3, March 2011, p. 399. the dictation of consumers by the health service provider, especially the private conglomerate. ${ }^{12}$

Capitalism can cause a growing number of private to invest resulting in competition and higher mobility of the health services provider, either in the private sector or Government. ${ }^{13}$ Capitalism also triggers some health sectors to evolve, from the doctors practice space, pharmacy, until the clinic into a complex industry. In the health care industry, the role of investor, i.e. the conglomerate becomes dominating. Besides health field, there is possibility of the pattern of a conglomerate outside the health sector that when the competition was tight, it could get a cross-subsidy (dumping) from nonhealth company's which get a huge profit. The health care industry has a high humanity dimension, to be said as a noble industry. In this case, the holder of the monopoly professions, such as doctors can prevent the decline of the noble profession and institution, i.e. the hospital. The capitalism affected the doctors, as it is stated that the existence of capitalism, the physician obtains a monopoly in the medical profession. Moreover, if shortage of doctors, especially specialists, the job market will favor the doctor. Medical profession has increased from the services sellers to small capitalists, regardless their practice, they also have a share in the clinics and hospitals. The industrialization process in health leads to more doctors practiced in a group, such as clinic (medical center in the mall or office building), if compared to the in-house practice. In medical-industrial complex, the hospital is the core while in the hospital, the doctor is the core. Specificity, sophistication, and the authority of the medical profession make it difficult to be replaced, compared to other professions. Moreover, specialist (and super specialists) were required and forced to work in many place due to their limited number.

12 Iwan Gardono Sujatmiko, "Privatisasi, Kapitalisme, dan Negara dalam Pelayanan Kesehatan (Suatu Studi Perubahan Sosial dalam Industri Kesehatan), Jurnal Masyarakat dan Budaya, Vol. 12 No. 3, 2010, p. 66.

13 Amy Gremminger White, "Paying for Patients: Choice of Law, Conflicting Interests, and Evolving Standards of Health Care Remuneration", Texas International Law Journal, Vol. 39 No. 2, 2004. p. 327. 
Such circumstances shows that the strategic role of doctor can actually lessen the negative impacts of industrialization or even commercialization of health services. Hospital depends on professional monopoly among doctors. Doctors can refuse the will of hospitals (and drug factories) which tend (overly) to take unreasonable profit from consumer (patient) ${ }^{14}$ especially if association of doctor is unified in opposing acts towards unreasonable comercialization.

Health service policy related to functional relationship among doctor, patient and hospital will be further discussed. However, functional relationship among doctor, patient and hospital will be discussed first from both sides. The information about the relationship is obtained from observation and interview from key informants and main informant concluded in these following tables.

Table 1. Patient's response to health services in hospital

\begin{tabular}{|c|c|c|c|c|c|c|c|}
\hline \multirow{3}{*}{ No. } & \multirow{3}{*}{ Type of Services } & \multicolumn{6}{|c|}{$\begin{array}{l}\text { Patient's Response } \\
\qquad(\mathrm{N}=30)\end{array}$} \\
\hline & & \multicolumn{2}{|c|}{$\begin{array}{c}\text { Very } \\
\text { Decent }\end{array}$} & \multicolumn{2}{|c|}{ Decent } & \multicolumn{2}{|c|}{$\begin{array}{l}\text { Less } \\
\text { Decent }\end{array}$} \\
\hline & & $f$ & $\%$ & $f$ & $\%$ & $f$ & $\%$ \\
\hline 1 & $\begin{array}{l}\text { Medical Services in } \\
\text { general }\end{array}$ & 14 & 47 & 16 & 53 & - & - \\
\hline 2 & Administrative Service & 9 & 30 & 21 & 70 & - & - \\
\hline 3 & Social Services & 6 & 20 & 24 & 80 & - & - \\
\hline
\end{tabular}

Table 2. Functional Relationship between Doctor and Patient during Hospitalization

\begin{tabular}{llllllll}
\hline & & \multicolumn{3}{c}{ Patient's Response $(\mathrm{N}=30)$} \\
\cline { 3 - 7 } No. & Relationship & \multicolumn{2}{c}{ Very } & \multicolumn{2}{c}{ Satisfied } & \multicolumn{2}{c}{ Less } \\
& & Category & Satisfied & Satisfied \\
\cline { 2 - 7 } & & f & $\%$ & f & $\%$ & f & $\%$ \\
\hline 1 & Hospitality & 11 & 37 & 19 & 63 & - & - \\
2 & Comfort & 12 & 40 & 18 & 60 & - & - \\
\hline
\end{tabular}

Table 3. Functional Relationship between Hospital and Doctor in Hospital

\begin{tabular}{|c|c|c|c|c|c|c|c|}
\hline \multirow{3}{*}{ No. } & \multirow{3}{*}{$\begin{array}{c}\text { Types of } \\
\text { Relationship }\end{array}$} & \multicolumn{6}{|c|}{ Doctor's Response } \\
\hline & & \multicolumn{2}{|c|}{$\begin{array}{c}\text { Very } \\
\text { Satisfied }\end{array}$} & \multicolumn{2}{|c|}{ Satisfied } & \multicolumn{2}{|c|}{$\begin{array}{c}\text { Less } \\
\text { Satisfied }\end{array}$} \\
\hline & & $f$ & $\%$ & $f$ & $\%$ & $f$ & $\%$ \\
\hline 1 & Professionalism & 8 & 80 & 2 & 20 & - & - \\
\hline 2 & $\begin{array}{l}\text { Patient } \\
\text { Satisfaction }\end{array}$ & 7 & 70 & 3 & 30 & - & - \\
\hline
\end{tabular}

14 George A. Chressanthis, Nayla G. Dahan, Kevin J Fandi. "The Effects of State Pharmacy Drug Product Selection Laws on Statin Patient Generic-to-Branded Drug SwitchBacks". The American Economist, SAGE Journal, Vol. 60 No. 1, May 2015, p. 26.
The functional relationship is the relationship among doctor, patient and hospital which daily occur in administrative activity, medical activeity or social activity ${ }^{15}$ in Dr. Moewardi Surakarta hospital and PKU Muhammadiyah Surakarta hospital. The functional relationship is dependent variable in this research. Dependent variable is one of variables besides antecedent and independent variable in this research. The following diagram is the relation among the variables in this research.

Image 1. Diagram of Relationship among Variables of Research.

\begin{tabular}{|c|c|c|}
\hline $\begin{array}{l}\text { Antecedent } \\
\text { Variable } \\
\text { Human } \\
\text { Rights } \\
\text { principles in } \\
\text { Health } \\
\text { - Positive law } \\
\text { which } \\
\text { contains } \\
\text { Human } \\
\text { Rights in } \\
\text { field of } \\
\text { health }\end{array}$ & $\begin{array}{l}\text { Independent } \\
\text { Variable } \\
\text { Policy/Political } \\
\text { health Service Law } \\
\text {-National Medium- } \\
\text { Term Development } \\
\text { Plan (RJPMN) 2015- } \\
2019 \\
\text {-Strategic Plan } \\
\text { (Renstra) 2015-2019 } \\
\text {-Long-Term Deve- } \\
\text { lopment Plan of } \\
\text { Health (RPJPK) } \\
\text { 2005-2025 }\end{array}$ & $\begin{array}{l}\text { Dependen } \\
\text { Variable } \\
\text { Functional } \\
\text { Relationship } \\
\text { among } \\
\text { Doctor, } \\
\text { Patient and } \\
\text { Hospital } \\
\text { - Doctor - } \\
\text { Patient } \\
\text { - Patient - } \\
\text { Hospital } \\
\text { - Doctor - } \\
\text { Hospital }\end{array}$ \\
\hline
\end{tabular}

The diagram explains the health service policy related to functional relationship among doctor, patient and hospital. It also explains future model of health service policy related to functional relationship among doctor, patient and hospital based on Human Rights (HAM) in Indonesia. The writer assumes that health service policy related to functional relationship among doctor, patient and hospital is based on overall law principles, conditions and regulations ${ }^{16}$ that have been agreed and authorized in form of applicable law in Indonesia including Law, Regulations, Decision and Ministerial Letter and Standard Operating Procedure (SOP) of hospital related to health services itself.

15 SR. Shrivastava, PS. Shivastava, J. Ramasamy. “Exploring the Dimensions of Doctor-Patient Relationship in Clinical Practices in Hospital Settings", International Journal of Health Policy and Management, Vol. 2 No. 4, May 2014, p. 159.

16 David A. Super, "The Modernization of American Public Law: Health Care Reform and Popular Constitutionalism", Stanford Law Review, Vol. 66 No. 4, April 2014, p. 898. 
Regarding functional relationship among doctor, patient and hospital, Indonesia as a law country has issued some law products which regulate health services. The health services that can respect, protect, serve and fulfill the health services. This is in line with health development plan namely health services policy is a policy on health service based on Human Rights in the field of health and health services; health development plan is reflected in strategic plan and referred to National Medium-Term Develop- ment Plan (RJPMN) arranged in Long-Term Development Plan of Health; law principles in health that are legality, balance, punctual, good intention, honesty, caution, loyal, openness; modern ethics principles that are autonomy, humble, give no pain, fairness, loyalty and honesty; and fulfill Human Rights principles including respect, protect, serve, fulfill; and related with functional relationship among doctor, patient and hospital that can be depicted in the following scheme.

Image 2. Health Services Policy Related to Functional Relationship among Doctor, Patient and Hospital.

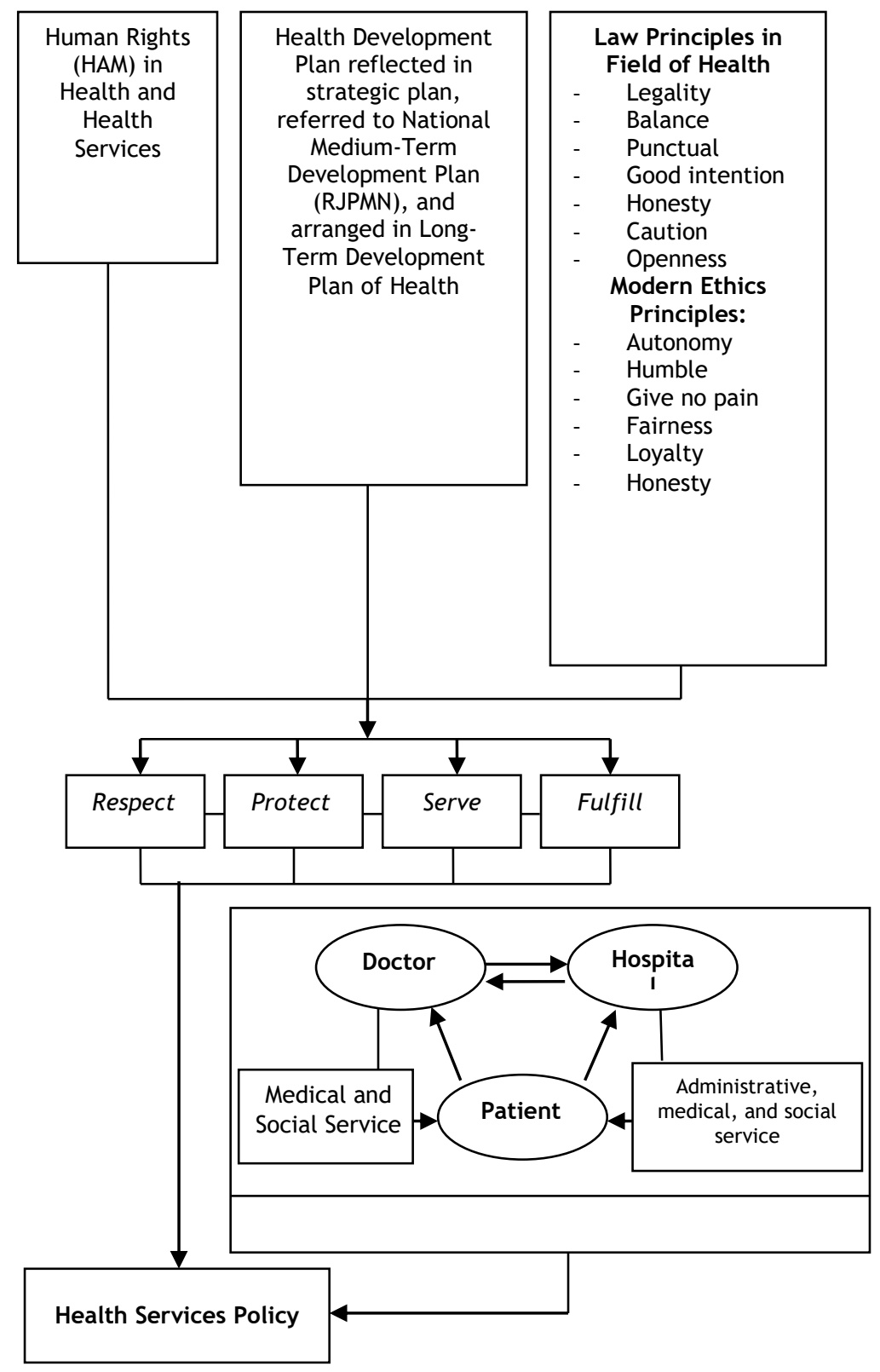


Functional Relationship Model among Doctor, Patient and Hospital in the Future According to Human Rights Related to Health Services in Indonesia

According to Human Rights, functional Relationship among doctor, patient and hospital in effort to respect, to protect and to fulfill is that a country has an obligation to implement human rights norm in right of health. It must fulfill these principles: availability of health services, accessibility, acceptance; and quality. The functional relationship will be related to patient's level of satisfaction towards the health services, in terms of medical record, ${ }^{17}$ service quality, ${ }^{18}$ problem/disease diagnosis, ${ }^{19}$ treatment criteria, ${ }^{20}$ characteristics and patient's quality, ${ }^{21}$

Functional relationship between doctor, patient, and hospital contains several doctrines, characteristics, norms, and Indonesian values that should be applied within functional relationship itself in administrative service, medical service, or social service. The doctrines are Leadership Trilogy from Ki Hajar Dewantara, ${ }^{22}$ firstly, ing ngarsa sung tuladha, which means hospital director must give a good example to his employee by acts with discipline, honest, tolerance, and fair; secondly, ing madya mangun karsa, which means hospital director must be

17 SM. Dunlay, KP. Alexander, Et.Al., "Medical Records and Quality of Care in Acute Coronary Syndromes: Results from CRUSADE", Journal of Archives of Internal Medicine, Vol. 168 No. 15, August 2008, p. 1692.

18 Aditi Naidu. "Factors Affecting Patient Satisfaction and Healthcare Quality", International Journal of Health Care Quality Assurance. Vol. 22 No. 4, 2009, p. 366.

19 Gareth Parry, Amelia Cline, Don Goldman, "Deciphering Harm Measurement", Journal of the American Medical Association. Vol. 307 No. 20. Mei 2012, p. 2155; DE. Newman-Toker, PJ. Pronovost. "Diagnostic Errors: The Next Frontier for Patient Safety", Journal of the American Medical Association, Vol. 301 No. 10, March 2009, p. 1060.

20 RO. Reid, MW. Friedberg, Et.Al. "Association between Physician Characteristics and Quality of Care", Journal of Archives of Internal Medicine, Vol. 170 No. 16, September 2010, p. 1442.

21 Mikael Rahmqvist, Ana Claudia, "Patient Characteristics and Quality Dimensions Related to Patient Satisfaction". International Journal for Quality in Health Care, Vol. 22 No. 2, April 2010, p. 86.

22 Darsiti Soeratman, 1985, Ki Hajar Dewantara, Jakarta: Departemen Pendidikan dan Kebudayaan, Proyek Buku Terpadu, p. 19-21; Ki Suratman, 1987, Pokok-pokok Ketamansiswaan, Yogyakarta: Majelis Luhur Persatuan Taman Siswa, p. 11-13 able to give motivation to his employees in order to make them work happily. Hospital director does not only gives command but also works together with his employees to realize their aims and purposes; and thirdly, tut wuri handayani, which means hospital director must be able to delegate the authority according to his employee competence. Hospital director must believe in his employees as long as they can perform their duty well with responsibility and full of dedication.

Tridharma doctrine from Mangkunegara I are, rumangsa melu handarbeni (has ownership feeling), wajib melu honggondheli/hangrungkebi (obligation to maintain), and mulat sarira hangrasa wani (self-awareness) which become the foundation philosophy (relationship doctrine within Pancasila) that arrange the relationship between management and employees. Furthermore, there is doctrine about human as Khalifah of Allah on Earth as rahmatan lil 'alamin (gift for all universe), human must keep the harmonization of microcosm (doctor and patient relationship) with macrocosm (hospital) and also maintain the harmonization of human relationship (in this case doctor, patient, hospital parties) with God, Allah SWT. ${ }^{23}$ Hospital and doctor has a responsibility to maintain the relationship with patient and vice versa. By performing medical service, whether in administrative or medical service, the hospital and doctor must be responsible to Allah SWT. By this responsibility, hospital and doctor will give a good quality medical service as a form of worship and instruction from Allah SWT.

$\mathrm{KH}$. Ahmad Dahlan doctrine is concluded within 7 (seven) philosophies and 17 groups of Al-Qur'an, especially tafsir Al-Ma'un which is the doctrine of social concern on poor people (the dhuafa'), moral education and integrity (akhlakul karimah), and doctrine of equality, fraternity, and fairness that become foundation in the establishment of Muhammadiyah Hospital recently as well as doctrine of characteristics

\footnotetext{
23 Nurhadiantomo, 2014, Hukum Progresif dan Kearifan Lokal: Telaah tentang Etika Kepemimpinan Lokal (Jawa) sebagai Sumber Pengayaan Asas, Surakarta: Universitas Muhammadiyah Surakarta, p. 68.
} 
shiddiq (honesty) amanah (trustworthy), tabligh (delivering), and fathonah (clever). This functional relationship also have to be based on all of Sila in Pancasila which are Believe in the one Supreme God, Just and civilized humanity, The unity of Indonesia, Democracy led by the wisdom of deliberations among representatives, Social justice for the whole of the people of Indonesian that can be simplified by diagram bellow:

Image 3. Model Diagram of functional relationship among doctor, patient, and hospital based on human rights related to Medical Service Policy in Indonesia



Those Indonesian values can be obtained through several focus group discussions with several law experts and medical experts appro- priate with the condition of functional relationship which is applicable in medical service. 
In researcher's opinion, functional relationship model among doctor, patient, and hospital based on human rights related to Med-ical Service Policy is caused by the rights of pa-tient to live, rights of information, and rights to selfdetermination. Therefore, other than refer-ring to all regulations on medical and medical service in Indonesia, it requires implementation of several Indonesian values including doctrine of leadership by Ki Hajar Dewantara, Tri Dharma by Mangkunegara I, and the harmonization between humans and Allah SWT (human as Khalifah of Allah on Earth). Also, KH. Ahmad Dahlan doctrine on social concern, moral education and integrity (akhlakul kharimah), and the doctrine of equality, fraternity, also fairness. As well as the doctrine of characteristics of shiddiq (honest), amanah (believable), tabligh (delivering), and fathonah (clever), and the implementation of Pancasila on medical services including administrative, medical, or social services. Hence, the functional relationship among doctor, patient, and hospital will not be contractual, transactional, and exploitative relationship but humanistic relationship. Besides, by the implementation of the whole Silas, a conducive relationship is established to conduct humanistic functional relationship among doctor, patient, and hospital based on Indonesian values.

By implementing the model above, the harmonization of doctor, patient, and hospital relationship (humanistic) can be materialized. By humanistic relationship, requirement of principle, norm, value and regulation that set on medical and medical service, the establishment according to Indonesian society interest, and fulfillment of human rights on health for all Indonesian people will be achieved.

\section{Conclusion}

Based on the research result, several points are concluded. First, basically, medical service is humanistic, it means its conduct is subject to humanity values. By the development of global capitalism, medical service becomes a kind of important commodity. The development of medical service law also grows rapidly. The mentioned Law of health is the comparison bet- ween supply and demand on medical service including what is offered by hospital. To make the law of medical service under control, the government intervention through various of regulations are needed. State has the obligation to make citizen live in prosperity including provides medical service as part of human rights implementation. Besides, medical service policy must be based on human rights of medical and medical service; the health establishment plan; law principles on medical service and principles of modern ethics; also fulfill human rights principles which are respect, protect, serve, and fulfill that related to functional relationship among doctor, patient, and hospital. Second, model functional relationship between doctor, patient, and hospital should be based on Pancasila implementation, Leadership Trilogy from Ki Hajar Dewantara, Tri Dharma from Mangkunegara I, Doctrine of KH. Ahmad Dahlan, and doctrine of shiddiq, amanah, tabligh, dan fathonah within administrative, medical, or social service.

\section{Suggestion}

The researcher recommends to the policy maker whether it is central or local government to formulate a law product that governs humanistic functional relationship among doctor, patient, and hospital since several given law products on medical or medical service only set on the surface. Furthermore, related to the functional relationship among doctor, patient, and hospital especially on medical service, the researcher recommends to all of medical service providers, especially doctor and hospital to implement Pancasila and Indonesian values in providing the medical service to realize a humanistic relationship. Furthermore, to increase administrative, medical, and social service, the researcher recommends to the hospital to use a good leadership characteristics, and to the doctor to be more communicative, friendly, and give comfort in order to increase patient's satisfaction.

\section{References}


Afandi, Dedi. "Hak Atas Kesehatan dalam Perspektif HAM". Jurnal Ilmu Kedokteran. Vol. 2 No. 1. Maret 2008. Pp. 1-14;

Astuti, Endang Kusuma. 2003. Hubungan Hukum antara Dokter dengan Pasien dalam Upaya Pelayanan Medis di Rumah Sakit. Semarang: Law Doctoral Program Universitas Diponegoro;

Banerjee, Amitav and Debmitra Sanyal. "Dynamics of Doctor-Patient Relationship: a Cross-sectional Study on Concordance, Trust, and Patient Enablement". Journal of Family and Community Medicine. Vol. 19 No. 1. January-April 2012. Pp. 12-19. DOI: 10.4103/2230-8229.94006;

Banka, Gaurav. Sarah Edgington.Namgyal Kyulo. Et.Al. "Improving Patient Satisfaction through Physician Education, Feedback, and Incentives". Journal of Hospital Medicine. Vol.10 No. 8. May 2015. Pp. 497502. DOI: $10.1002 / \mathrm{jhm} .2373$;

Brody, Howard and Donald W Light. "The Inverse Benefit Law: How Drug Marketing Undermines Patient Safety and Public Health". American Journal of Public Health. Vol. 101 No. 3. March 2011. Pp. 399-404.DOI: 10.2105/AJPH.2010.199844;

Chressanthis, George A. Nayla G Dahan and Kevin J Fandi. "The Effects of State Pharmacy Drug Product Selection Laws on Statin Patient Generic-to-Branded Drug Switch-Backs". The American Economist. SAGE Journals. Vol. 60 No. 1. May 2015. Pp. 26-51. DOI: 10.1177/05694345150600 0104;

Clever, Sarah L. Et.Al. "Does Doctor-Patient Communication Affect Patient Satisfaction with Hospital Care? Results of an Analysis with a Novel Instrument Variable". Health Services Research Journal. Vol. 43 No.5. October 2008. Pp. 15051519. DOI: $10.1111 /$ j.1475-6773.2008.008 49.x;

Daly, Angela. "The Law and Ethics of 'Self Quantified' Health Information: an Australian Perspective". International Data Privacy Law. Vol. 5 No. 2. May 2015. Pp. 144-155. DOI: 10.1093/idpl/ipv001;

Dang, Van Mo. Et.Al. "Medical Record-Keeping Patient Perception of Hospital Care Quality". International Journal of Health Care Quality Assurance. Vol. 27 No. 6. 2014. Pp. 531-543. DOI: 10.1108/IJHCQA-06-20 13-0072
Dunlay, SM. Et.Al. "Medical Records and Quality of Care in Acute Coronary Syndromes: Results from CRUSADE". Journal of Archives of Internal Medicine. Vol. 168 No. 15. August 2008. Pp. 1692-1698. DOI: 10.1001/ archinte.168.15.1692;

Ferdi, Roni. "Kebijakan Pelayanan Kesehatan Sistem Desentralisasi". Jurnal Online Dinamika. Vol. 1 No. 2. Desember 2008. Pp. 67-71;

Greer, Scott L. Et.Al. "Health Law and Policy in the European Union". The Lancet. Vol. 381 No. 9872. Maret 2013. Pp. 1135-1144. DOI: 10.1016/50140-6736(12)62083-2;

Ibrahim, Anis. "Telaah Yuridis Perkembangan Hukum Positif tentang Hak Asasi Manusia (HAM) di Indonesia". Jurnal Hukum Argentum. Vol. 9 No. 2. June Edition 2010;

James, John T. "A New, Evidence-based Estimate of Patient Harms Associated with Hospital Care". Journal of Patient Safety. Vol. 9 No. 3. September 2013. Pp. 122128. DOI: 10.1097/PTS.0b013e3182948a 69;

Kavanagh, Kevin T. Et.Al. "Estimating HospitalRelated Deaths Due to Medical Error: a Perspective from Patient Advocates". Journal of Patient Safety. Vol. 13 No. 1. March 2011. Pp. 1-5. DOI: 10.1097/PTS.00 00000000000364;

Keller, Anita C. Et.Al. "The Relationship between Hospital Patients' Ratings of Quality of Care and Communication". International Journal for Quality in Health Care. Vol. 26 No. 1. February 2014. Pp. 26-33. DOI: $10.1093 /$ intqhe/mzq083;

Landrigan, CP. Et.Al. "Temporal Trends in Rates of Patient Harm Resulting from Medical Care". New England Journal of Medicine. Vol. 363 No. 22. November 2010. Pp. 2124-2134. DOI: 10.1056/NEJMsa1004404;

Mosadeghrad, Ali Mohammad. "Healthcare Service Quality: Towards a Broad Definition". International Journal of Health Care Quality Assurance. Vol. 26 No. 3. Nov 2013. Pp. 203-219. DOI: $10.1108 / 095268$ 61311311409;

Naidu, Aditi. "Factors Affecting Patient Satisfaction and Healthcare Quality". International Journal of Health Care Quality Assurance. Vol. 22 No. 4. 2009. Pp. 366381. DOI: 10.1108/09526860910964834;

Newman-Toker, DE., Pronovost, PJ. "Diagnostic Errors: The Next Frontier for Patient Sa- 
fety". Journal of the American Medical Association. Vol. 301 No. 10. March 2009. Pp. 1060-1062. DOI: 10.1001/jama.2009. 249;

Nurhadiantomo. 2014. Hukum Progresif dan Kearifan Lokal: Telaah tentang Etika Kepemimpinan Lokal (Jawa) sebagai Sumber Pengayaan Asas. Surakarta: Universitas Muhammadiyah Surakarta;

Parry, G. A Cline and D Goldman. "Deciphering Harm Measurement". Journal of the American Medical Association. Vol. 307 No. 20. March 2009. Pp. 2155-2156. DOI: 10. 1001/jama.2012.3649;

Rahmqvist, Mikael and Ana Claudia. "Patient Characteristics and Quality Dimensions Related to Patient Satisfaction". International Journal for Quality in Health Care. Vol. 22 No. 2. April 2010. Pp. 86-92. DOI: 10.1093/intqhc/mzq008;

Reid, RO. Et.Al. "Association between Physician Characteristics and Quality of Care". Journal of Archives of Internal Medicine. Vol. 170 No. 16. September 2010. pp. 1442-1449. DOI: 10.1001/archinternmed. 2010.307;

Rosenbaum, Sara. Et.Al. "Case Studies at Denver Health: 'Patient Dumping' in the Emergency Department Despite EMTALA, the Law that Banned it". Health Affairs 31. No. 8. August 2012. pp. 1749-1756. DOI: $10.1377 /$ hlthaff.2012.0517;

Shrivastava, SR. PS Shivastava and J Ramasamy. "Exploring the Dimensions of Doctor-Patient Relationship in Clinical Practices in Hospital Settings". International Journal of Health Policy and Management, Vol. 2 No. 4. May 2014. Pp. 159-160. DOI: 10. 15171/IJHPM.2014.40;
Soeratman, Darsiti. 1985. Ki Hajar Dewantara. Jakarta: Departemen Pendidikan dan Kebudayaan, Proyek Buku Terpadu;

Sujatmiko, Iwan Gardono. "Privatisasi, Kapitalisme, dan Negara dalam Pelayanan Kesehatan (Suatu Studi Perubahan Sosial dalam Industri Kesehatan). Jurnal Masyarakat dan Budaya. Vol. 12 No. 3. 2010. Pp. 66-67. DOI: 10.14203/jmb.v12i3.160;

Super, David A. "The Modernization of American Public Law: Health Care Reform and Popular Constitutionalism". Stanford Law Review. Vol. 66 No. 4. April 2014. Pp. 873951.

Suratman, Ki. 1987. Pokok-pokok Ketamansiswaan. Yogyakarta: Majelis Luhur Persatuan Taman Siswa.

Watanabe, Takashi. Et.Al. "Assessment of Japanese Stimulant Control Law Offenders Using the Addiction Severity Index-Japanese Version: Comparison with Patients in Treatment Settings". International Journal of Enviromental Research and Public Health, Vol. 6 No. 12. December 2009. Pp. 3056-3069. DOI: 10.3390/ijerph6123 056;

Weiner, SJ. Et.Al. “Contextual Errors and Failures in Individualizing Patient Care: A Multicenter Study". Annals of Internal Medicine. Vol. 153 No. 2. July 2010. Pp. 69-75. DOI: 10.7326/0003-4819-153-2-201 007200-00002;

White, Amy Gremminger. "Paying for Patients: Choice of Law, Conflicting Interests, and Evolving Standards of Health Care Remuneration". Texas International Law Journal. Vol. 39 No. 2. 2004. Pp. 327-345. 